\title{
VELVET LUPINE (LUPINUS LEUCOPHYLLUS) POPULATION CYCLES WITH PRECIPITATION
}

\author{
M.H. Ralphs ${ }^{1,3}$, E. Motteram ${ }^{2}$, and K.E. Panter ${ }^{1}$
}

\begin{abstract}
Velvet lupine (Lupinus leucophyllus Dougl. ex Lindl) contains the teratogenic alkaloid anagyrine that causes a crooked calf syndrome. An outbreak of crooked calves occurred in the Channeled Scabland region of eastern Washington in 1997 following 2 years of above-average precipitation. Following this catastrophic loss, we began studies to track velvet lupine density and relate its population cycle to precipitation. In the first study, five $1-\mathrm{m}^{2}$ quadrats were systematically placed in dense lupine patches at each of 5 locations throughout the scabland region. The quadrats were permanently marked and the number of seedlings and established mature plants were counted biweekly or monthly through the growing seasons of 2001-2005. In the second study, four $1 \times 30$-m belt transects were established at each of 3 additional locations in the scabland region. The number of seedlings and mature lupine plants were counted within these transects in June or July each year from 2002 to 2009. A third study was conducted to determine the slope or aspect where lupine was most abundant. Ten sites were located along the Cow Creek drainage which runs through the region. At each site, $1 \times 10$-m belt transects were established in alluvial bottoms, slopes, and shallow rocky ridges. In study 1 , density of mature lupine plants generally declined between 2001 and $2005(P<0.001)$ and was correlated with spring precipitation $(r=0.77)$. In study 2 , density of mature lupine plants differed between years $(P<0.001)$, declining from 2002 through 2005 but increasing in 2007 in response to heavy precipitation the previous fall and spring (mature lupine plants vs. fall precipitation, $r=0.75$; and mature lupine plants vs. spring precipitation, $r=0.62)$. Density of lupine was greatest on slopes $\left(2.6\right.$ plants $\left.\cdot \mathrm{m}^{-2}\right)$, intermediate on alluvial bottoms $\left(1.5\right.$ plants $\left.\cdot \mathrm{m}^{-2}\right)$, and lowest on shallow rocky ridges $\left(0.26\right.$ plants $\left.\cdot \mathrm{m}^{-2}\right)$. Velvet lupine populations appear to cycle with climatic patterns, increasing following wet years and dying back in drought.
\end{abstract}

Resumen.-El altramuz velvet (Lupinus leucophyllus Dougl. ex Lindl) contiene el alcaloide teratogénico anagirina, el cual provoca el síndrome del ternero toricdo. Un brote de este síndrome ocurrió en la región Scabland, al este de Washington en 1997, después de dos años de precipitación por encima del promedio. Luego de esta pérdida catastrófica, iniciamos estudios para registrar la densidad del altramuz velvet y relacionar su ciclo poblacional con la precipitación. En el primer estudio, cinco cuadrantes de $1 \mathrm{~m}^{2}$ se colocaron sistemáticamente en manchones densos de altramuz en 5 sitios a lo largo de la región Scabland. Marcamos los cuadrantes permanentemente y se contó el número de plántulas y plantas maduras establecidas cada dos semanas o mensualmente durante la temporada de crecimiento de los años 2001-2005. En el segundo estudio, se establecieron cuatro transectos de $30 \mathrm{~m}$ en cada uno de 3 sitios adicionales en la región Scabland. Se contó el número de plántulas y plantas maduras de altramuz en estos transectos en junio o julio de cada año de 2002 a 2009. Se llevó a cabo un tercer estudio para determinar la pendiente o aspecto de los lugares donde el altramuz era más abundante para determinar su preferencia de hábitat. Se ubicaron diez sitios a lo largo de la cuenca de desagüe de Cow Creek, la cual atraviesa la región. En cada sitio, se establecieron transectos de $10 \mathrm{~m}$ en el lecho aluvial, las pendientes y crestas rocosas bajas. En el estudio 1, la densidad de plantas maduras de altramuz generalmente declinó entre 2001 y $2005(P<0.001)$ y estuvo correlacionada con la precipitación de primavera $(r=0.77)$. En el estudio 2, la densidad de plantas maduras de altramuz varió entre años $(P<0.001)$, disminuyó de 2002 a 2005 , pero aumentó en 2007, respondiendo a la abundante precipitación durante el otoño y la primavera anteriores (coeficiente de correlación entre plantas maduras de altramuz y la precipitación de otoño, $r=0.75$ y la precipitación primaveral, $r=0.62)$. El altramuz alcanzó su máxima densidad en pendientes $\left(2.6\right.$ plantas $\left.\cdot \mathrm{m}^{-2}\right)$ en comparación con el lecho aluvial $\left(1.5\right.$ plantas $\left.\cdot \mathrm{m}^{-2}\right)$, o a las crestas rocosas bajas $\left(0.26\right.$ plantas $\left.\cdot \mathrm{m}^{-2}\right)$. Las poblaciones del altramuz Velvet parecen fluctuar con los ciclos climáticos, incrementando después de años húmedos y mermando en años secos.

Lupines are some of the most conspicuous forbs on western rangelands. Many lupines are typical "increaser" species, increasing in abundance following disturbance. Following the eruption of Mount St. Helens in 1980, extensive research was conducted on recolo- nization of plant communities inundated by ash. Various species of lupine were primary colonizers that dominated plant communities (Black and Mack 1986, Morris and Wood 1989, Braatne and Bliss 1999, Del Moral and Jones 2002). Lupine species also dominated plant

${ }^{1}$ USDA/ARS Poisonous Plant Research Lab, Logan, UT 84341

${ }_{2}^{2}$ Field Investigative Unit, College of Veterinary Science, Washington State University, Pullman, WA.

32E-mail: michael.ralphs@ars.usda.gov 
communities following fires in lodgepole pine forests (Tracy and McNaughton 1997), pinyon and juniper (Rau et al. 2008), and sagebrush (M.H. Ralphs personal observation).

Populations of some lupine species also appear to cycle. An increase in density of velvet lupine (Lupinus lecuophyllus Dougl. ex Lindl) was observed in the scabland region of eastern Washington during the wet period of the late 1990s. As a result, a catastrophic loss of calves occurred throughout this region in 1997 (Gay et al. 2007). Velvet lupine contains the teratogenic alkaloid anagyrine that causes birth defects in calves (Shupe et al. 1967, Keeler 1976). There is a need to understand the population cycle of velvet lupine and the factors that influence its increase and decline.

The hypothesis of this study was that velvet lupine germinates and establishes in wet years and dies back in drought. The objective of this study was to correlate lupine density with seasonal precipitation over a 9 -year period in the Channeled Scabland region of eastern Washington. A second objective was to determine the preferred habitat of velvet lupine in the various sites or aspects of land forms in this region.

\section{Methods}

The study was conducted in the Channeled Scabland region of eastern Adams County in east central Washington. The site was characterized by basalt plateaus and valleys carved by historic floods from the ancient lake Missoula about 15,000 years ago, when ice dams broke and torrents of water and ice scoured and eroded the deep Palouse soil during the last Ice Age. The original plant community was a Palouse prairie, with the uplands dominated by bluebunch wheatgrass (Pseudoroegneria spicata [Pursh] A. Löve) and Idaho fescue (Festuca idahoensis Elmer) and the bottoms by basin wildrye (Leymus cinereus [Scribner \& Merrill] A. Löve). The entire region has been degraded to annual grassland. The bottoms now are dominated by cheatgrass (Bromus tectorum L.) and weedy forbs such as fiddleneck (Amsinckia intermedia Fisch. \& Mey), tansy mustard (Descurainia pinnata [Walt.] Britt), and rush skeletonweed (Chondrilla juncea L.). The shallow rocky ridges support sparse plants of bluebunch wheatgrass, Idaho fescue, and Sandberg bluegrass (Poa sandbergii Vasey). Velvet lupine is the prominent deep-rooted perennial forb on the site. Horsebrush (Tetradymia canescens DC.) and rabbitbrush (Chrysothamnus nauseosus [Pall. ex Pursh] Britt.) are dominant sprouting shrubs, which suggests a relatively frequent fire regime.

Precipitation records were obtained from the Lind, Washington, recording site (NOAA Western Regional Climate Center), located on the western edge of the scabland region. Seasonal amounts were calculated for the water years starting in fall (October-December), winter (January-March), spring (April-June), and summer (July-September); and amounts were also calculated for total annual precipitation. In the 2 density studies described below, correlations were run between density of lupine age classes (mature plants and seedlings) and current year seasonal and total precipitation, and for seasonal and total precipitation lagged one year to reflect the influence of the previous year's precipitation on the current year's density. The strongest correlations were selected to describe the relationship of precipitation with establishment and mortality of seedling and mature velvet lupine plants.

\section{Quadrat Density Study: 2001-2005}

Five locations were selected throughout the scabland region (Table 1). At each location, 5 permanent $1-\mathrm{m}^{2}$ quadrats were systematically placed in dense lupine patches and marked with rebar stakes in the corners. Wires were strung over the quadrat frame, creating 64 square cells $(12.5 \mathrm{~cm}$ on a side). The number and age class of velvet lupine plants within each cell were recorded. Recordings were made monthly (May-August) in 2001 and 2002 and biweekly in 2003-2005. The number of seedlings (individuals without true stems and not exceeding $18 \mathrm{~cm}$ in height in the growing season) and mature plants were transcribed from the data sheets for each quadrat and compared among locations, over years, and over the growing season. The maximum number of mature lupine plants generally occurred in June, and was used to compare the established population over years. The number of mature plants was analyzed by repeated measures mixed model analysis of variance (ANOVA), comparing locations as a fixed effect and years as the repeated measures. Quadrats represented the random variable.

Number of seedlings were compared over the growing season to evaluate seasonal mortality. Since the number of readings and the times at 
TABLE 1. Study site attributes, Channeled Scabland region, Adams County, Washington.

\begin{tabular}{|c|c|c|c|c|}
\hline Study & Site & Coordinate & Soils & Ecological site \\
\hline \multirow[t]{5}{*}{ Quadrat: 2001-2005 } & Pasture 1492 & $46.8881^{\circ} \mathrm{N}, 118.2262^{\circ} \mathrm{W}$ & $\begin{array}{l}\text { Roloff-Starbuck, extremely } \\
\text { rocky silt loam }\end{array}$ & Stony \\
\hline & Green Lake & $46.8304^{\circ} \mathrm{N}, 118.1597^{\circ} \mathrm{W}$ & $\begin{array}{l}\text { Anders-Kuhl, extremely } \\
\text { rocky silt loam }\end{array}$ & Loamy \\
\hline & Boulder & $46.9602^{\circ} \mathrm{N}, 118.2713^{\circ} \mathrm{W}$ & $\begin{array}{l}\text { Ritzville silt loam, Farrell } \\
\text { very fine sandy loam }\end{array}$ & Loamy \\
\hline & Corral & $46.9213^{\circ} \mathrm{N}, 118.2371^{\circ} \mathrm{W}$ & Chard silt loam & Cool loamy \\
\hline & Pole & $46.0513^{\circ} \mathrm{N}, 118.0458^{\circ} \mathrm{W}$ & Benge gravely silt loam & Loamy bottom \\
\hline \multirow{3}{*}{ Transect: 2002-2009 } & North & $46.0627^{\circ} \mathrm{N}, 118.0451^{\circ} \mathrm{W}$ & Chard silt loam & Cool loamy \\
\hline & South & $46.8301^{\circ} \mathrm{N}, 118.1642^{\circ} \mathrm{W}$ & $\begin{array}{l}\text { Chard silt loam, Benge silt } \\
\text { loam }\end{array}$ & $\begin{array}{l}\text { Cool loamy, } \\
\text { loamy bottom }\end{array}$ \\
\hline & West & $46.9225^{\circ} \mathrm{N}, 118.2172^{\circ} \mathrm{W}$ & Benge gravely silt loam & Loamy bottom \\
\hline Aspect & Cow Creek & $46.9238^{\circ} \mathrm{N}, 118.2105^{\circ} \mathrm{W}$ & $\begin{array}{l}\text { Emdent extremely rocky } \\
\text { silt loam }\end{array}$ & Alkali bottom \\
\hline
\end{tabular}

which they were taken differed each year, the mean number of seedlings was calculated each month and the monthly value was used to represent mortality over the summer. Seedling numbers were evaluated in a mixed model ANOVA comparing locations as a fixed effect, years and month as repeated measures, and quadrats as a random effect.

\section{Transect Density Study: 2002-2009}

Three locations were selected for monitoring (Table 1), and 4 transects were established at each location. Transects were read once each year in June or July. The site at the northern end of the region was located in a long relatively flat valley bottom with basalt rock outcroppings. The site at the southern end of the region was characterized by eroded basalt outcroppings and swales. The site on the western edge of the region was along Cow Creek, the main waterway of the area.

Four permanent belt transects were established at each location in 2002 and read annually. Transects were $1 \mathrm{~m}$ wide and $30 \mathrm{~m}$ long. The number of lupine seedlings and established plants were counted in each of the transects. The data were analyzed by repeated measures mixed model ANOVA, comparing locations as a fixed effect, year as a repeated measure, and transects as a random factor.

\section{Aspect Study}

The preferred habitat of velvet lupine was determined within the land forms or aspect. The bottomland aspect was characterized by depressions and valley bottoms. Top soil was
$>40 \mathrm{~cm}$ deep and had been eroded from the ridges and slopes. The original plant community was dominated by basin wildrye but has been degraded to annual species, such as cheatgrass, fiddleneck, tansy mustard, prickly lettuce (Lactuca serriola L.), and black mustard (Brassica nigra [L.] Koch).

The slope aspect had moderately shallow soil and was dominated by cheatgrass and medusahead (Taeniatherum caput-medusae [L.] Nevski), but needle and thread grass (Stipa comata Trin. \& Rupr.) occurred occasionally. Rush skeletonweed (Chondrilla juncea L.) was the dominant forb, and velvet lupine occurred frequently on the slopes. Horsebrush and rabbitbrush were dominant sprouting shrubs.

Soils on ridge-top aspect were very shallow and supported sparse plants of Idaho fescue, bluebunch wheatgrass, and Sandberg bluegrass.

Lupine density was measured on the 3 aspects in 2002 and 2003. Ten locations were selected through the Cow Creek drainage, having the 3 aspects on contiguous sites. A $1 \times 10$-m belt transect was established in each aspect, and the number of lupine plants in each of the following size classes were counted: seedling (leaflets without a central stem), juvenile (elongated stem but no reproductive parts), and mature (buds, flowers, or pods present). The density of each age class was analyzed by mixed model ANOVA comparing differences between the fixed effects of location, aspect, and year. There was an aspect $\times$ year interaction $(P<0.01)$, so the model was reduced and aspects were analyzed separately for differences in density between years. 

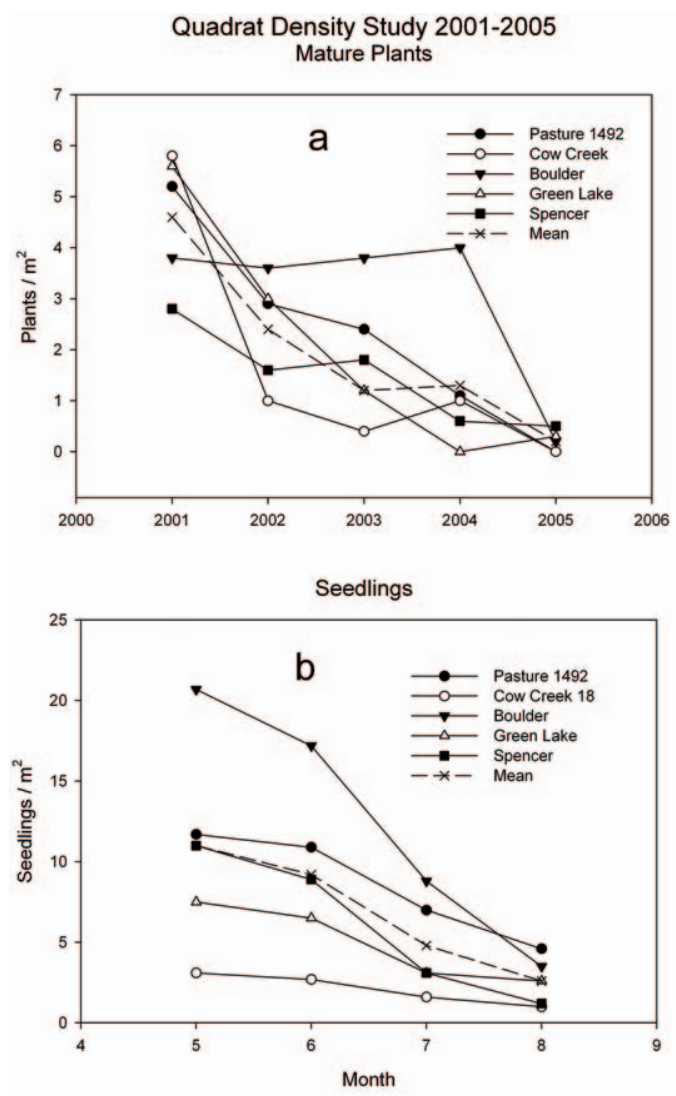

Fig. 1. Density of (a) established mature velvet lupine (Lupinus leucophyllus) plants in each year and (b) seedlings over the growing season in the quadrat density study, 2001-2005.

\section{RESUlts}

Quadrat Density Study: 2001-2005

There was no main effect difference in mature lupine density between locations $(P=0.69)$. There was a general decline in density of mature lupine plants over years $(P<0.0001$; Fig. 1a) in all pastures except Boulder (location $\times$ year interaction: $P=0.0015)$. In the Boulder pasture, lupine density maintained an average of 4 plants $\cdot \mathrm{m}^{-2}$ from 2001 to 2004 , then the plants died in 2005, as they did in the other pastures. The Boulder pasture was part of an intensive short-duration grazing system. It was heavily grazed by a large number of cattle for a short period of time each year. We noted that most of the mature lupine plants were grazed down each year. In contrast to the result for most forbs, this severe defoliation may have prevented the gradual die-off of lupine observed in the other
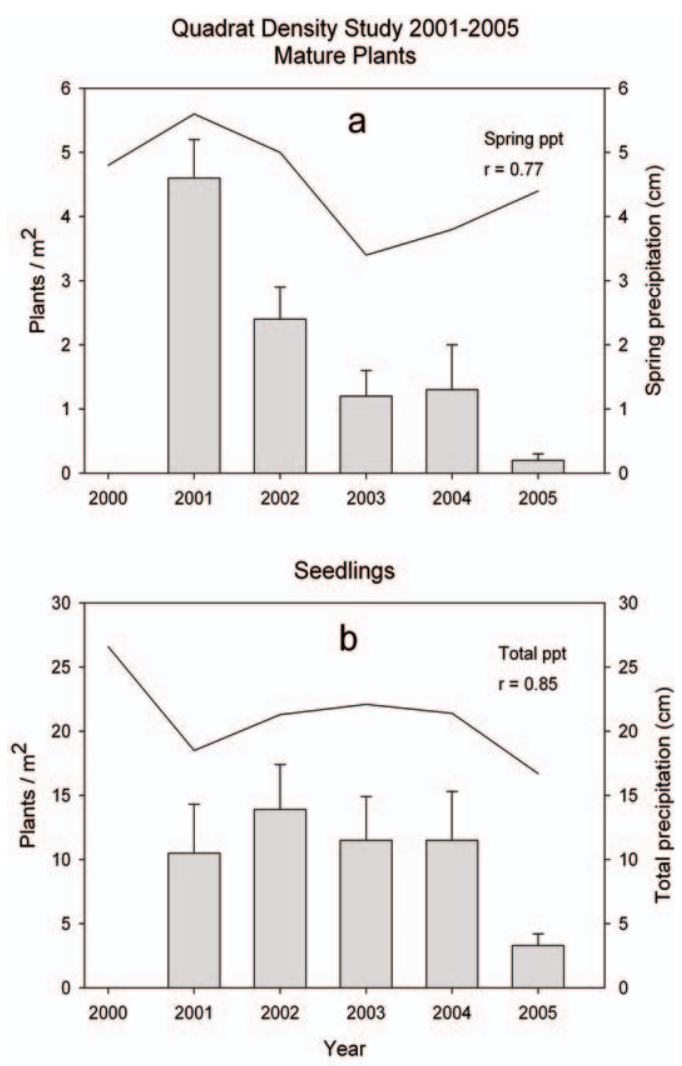

Fig. 2. Correlation of precipitation (lines) with mean density (bars) of mature velvet lupine (Lupinus leucophyllus) (a) plants and (b) seedlings in the quadrat density study, 2001-2005. Error bars represent standard errors, and $r=$ correlation coefficient with spring or total precipitation.

pastures. Grazing all vegetation uniformly may have prevented depletion of the soil moisture (Ralphs 2009), allowing lupine to recover and grow following defoliation, while annual grasses senesced.

Lupine seedling density differed among locations $(P=0.0002$; Fig. $1 \mathrm{~b})$. Boulder pasture had the greatest number of seedlings, likely due to the heavy grazing and associated disturbance. Seedlings in all pastures declined over the growing season $(P<0.0001$; Fig. 1b). Seeds germinated as temperatures warmed in May and June and because the soil was moist. As the soil profile dried over the summer, most of the seedlings died.

Spring precipitation was positively correlated with mature lupine density $(r=0.77$; Fig. 2a). As spring precipitation declined in 2002 and 2003, mature lupine declined. Seedling density was positively correlated with total 

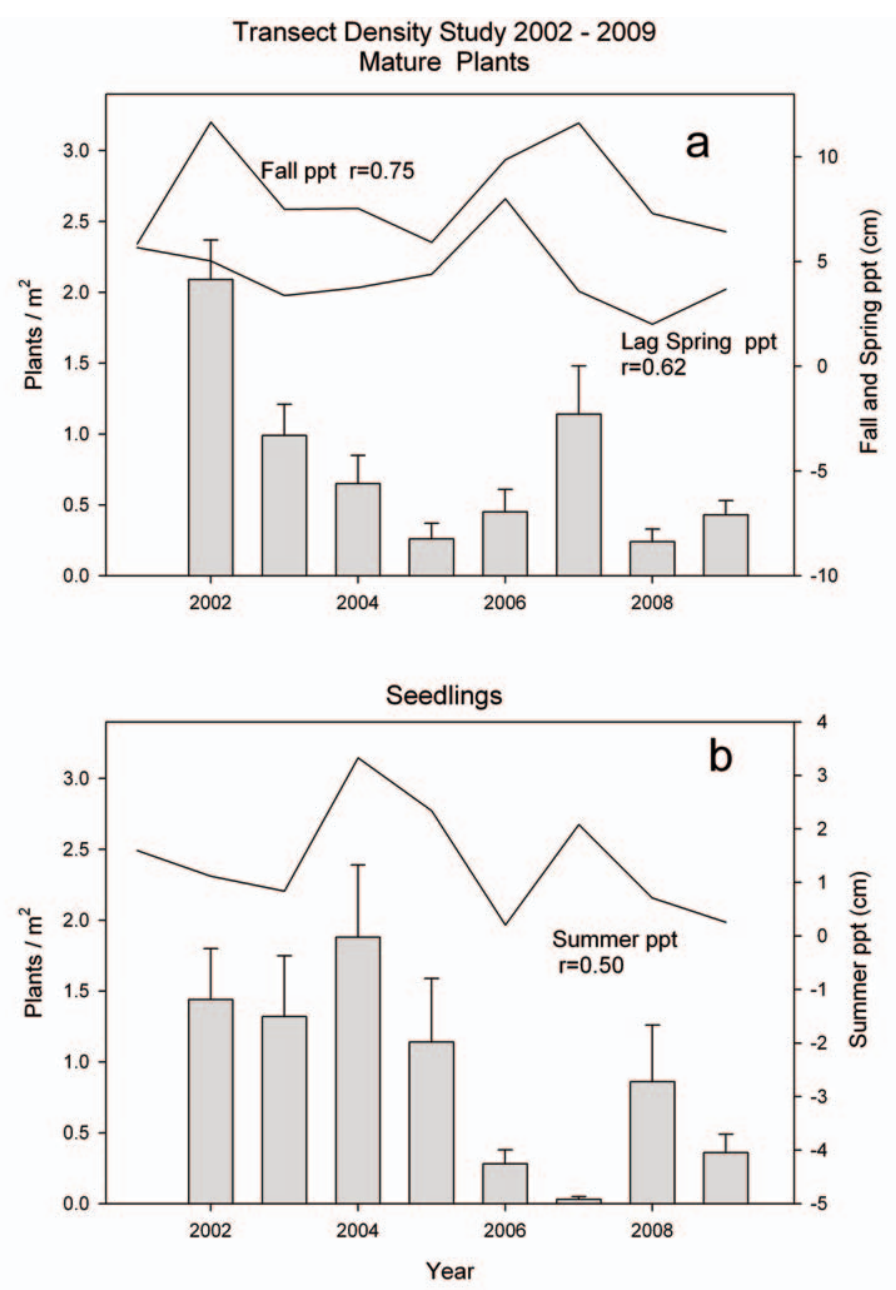

Fig. 3. Correlation of precipitation (lines) with density (bars) of mature velvet lupine (Lupinus leucophyllus) plants (a) and seedlings (b) in the transect density study, 2002-2009. Error bars are standard errors, and $r=$ correlation coefficient with seasonal precipitation.

water year precipitation $(r=0.85$; Fig. $2 \mathrm{~b})$. As precipitation declined in 2001 and again in 2005 , seedling density declined.

Transect Density Study: 2002-2009

There were no differences between location in this study $(P=0.41)$, but density of mature plants differed among years $(P<0.0001)$. There was a general decline in density from 2002 to 2005, with an increase in 2006 and 2007, followed by a die-off in 2008 and 2009 (Fig. 3a).

There were moderate correlations between the previous year's precipitation and density of mature lupine plants in the next year (Fig. 3a). Declines in fall precipitation apparently caused a decline in lupine density in 2003-2005 and again in 2008-2009 (Fig. 3a). Increase in precipitation during the previous spring $(r=0.62)$, and especially in the current water year fall precipitation $(r=0.75)$, appeared to increase density of established lupine plants in 2007. There was a weak correlation between seedlings and summer precipitation ( $r=0.50$; Fig. 3b). Summers in the region are typically dry, averaging only $2.75 \mathrm{~cm}$ of precipitation.

\section{Aspect Study}

Lupine density was greatest on the slopes between the deep soils in the bottoms and the rocky ridge tops $(P<0.001$; Fig. 4$)$. Mean 


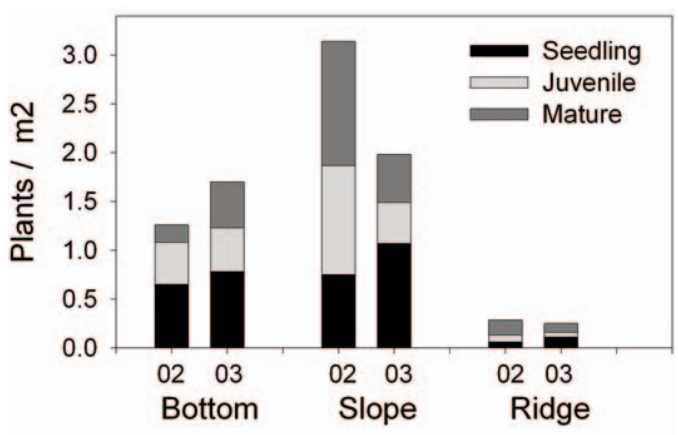

Fig. 4. Density of velvet lupine (Lupinus leucophyllus) age classes and land form or aspect.

density of total lupine plants on the slopes averaged 2.6 plants $\cdot \mathrm{m}^{-2}$, compared to 1.5 in the bottoms and only 0.26 on the ridges. There was a year $\times$ aspect interaction in the density of mature and juvenile plants $(P<0.01)$. On the slope aspect, mature plants declined from 1.27 to 0.49 plants $\cdot \mathrm{m}^{-2}$ from 2002 to 2003. Juvenile plants declined from 1.12 to 0.42 plants $\cdot \mathrm{m}^{-2}$. There were no differences on the other aspect types

\section{Discussion}

Velvet lupine's preferred habitat appears to be the slopes between the shallow ridge tops and the alluvial bottoms. The deep bottom soils accumulated from erosion of the ridges and slopes. Cheatgrass dominated the site, was very dense, and grew $70 \mathrm{~cm}$ tall, suggesting a very fertile environment and a high soil water-holding capacity in such a low precipitation zone. We speculate that competition from cheatgrass and other forbs reduced density of lupine on this site. Vegetation on the shallow ridge tops was sparse and dominated by the native bunchgrasses. Soils were very shallow, ranging from a few centimeters to the outcropping of the basalt bedrock. We speculate that the shallow soils limited lupine density on this aspect. Soil depth on the slopes varied. Height of cheatgrass and medusahead was $15-20 \mathrm{~cm}$, and other forbs were abundant. We speculate that the deep-rooted lupine was able to compete well and dominate this aspect.

Although our quadrat and transect density studies covered different years, density of established mature lupine plants was similar in the years of overlap. The data were com- bined to provide a general illustration of the decline in lupine density over the course of the study (Fig. 5). Ranchers reported that lupine density was high during and following the wet years of 1995-1997, when the catastrophic loss to crooked calf syndrome occurred. It appears that the velvet lupine population declined during the subsequent years of belowaverage precipitation. Our data show a direct correlation between precipitation and density of lupine in the following year.

Considerable research has been conducted on the relationship of precipitation and grass production, particularly the effect of prior years' precipitation. Cable (1975) reported that herbage production of warm-season grasses in Arizona depends on environmental conditions during 2 critical times: the prior year's JuneSeptember precipitation, during which new tillers are formed; and August precipitation, during the current growing season when tillers grow out. Similar responses were obtained to antecedent precipitation in cool-season grasses of the Pacific Northwest (Sneva and Britton 1983) and in warm-season grasses in the southwestern United States (Sosebee et al. 2003).

Populations of other important poisonous plants, particularly the locoweeds (Ralphs et al. 2003), cycle with weather conditions (Ralphs and Jensen 2007) increasing in wet years and dying back in drought. Pfister and Cook (2011) reported that density of low larkspur (Delphinium nuttallianum) had a strong positive relationship with previous winter and spring precipitation and an inverse relationship with summer temperature in the previous year. Low larkspurs form buds for the next growing season, and environmental stress from summer drought and high temperatures reduces the number of plants that break dormancy and grow the following year.

Tall larkspur is a long-lived perennial forb similar to lupine. It grows each year from buds on the crown of a long tap root. These buds begin to swell during the previous growing season and remain active and grow slowly over the winter so they are ready to initiate rapid growth when snow melts (Kreps 1969). Stress during active growth greatly restricted carbohydrate flow to the crown and developing buds, resulting in a 50\%-60\% reduction of stalks the next year (Ralphs and Gardner 2001). Likewise, environmental conditions (primarily 


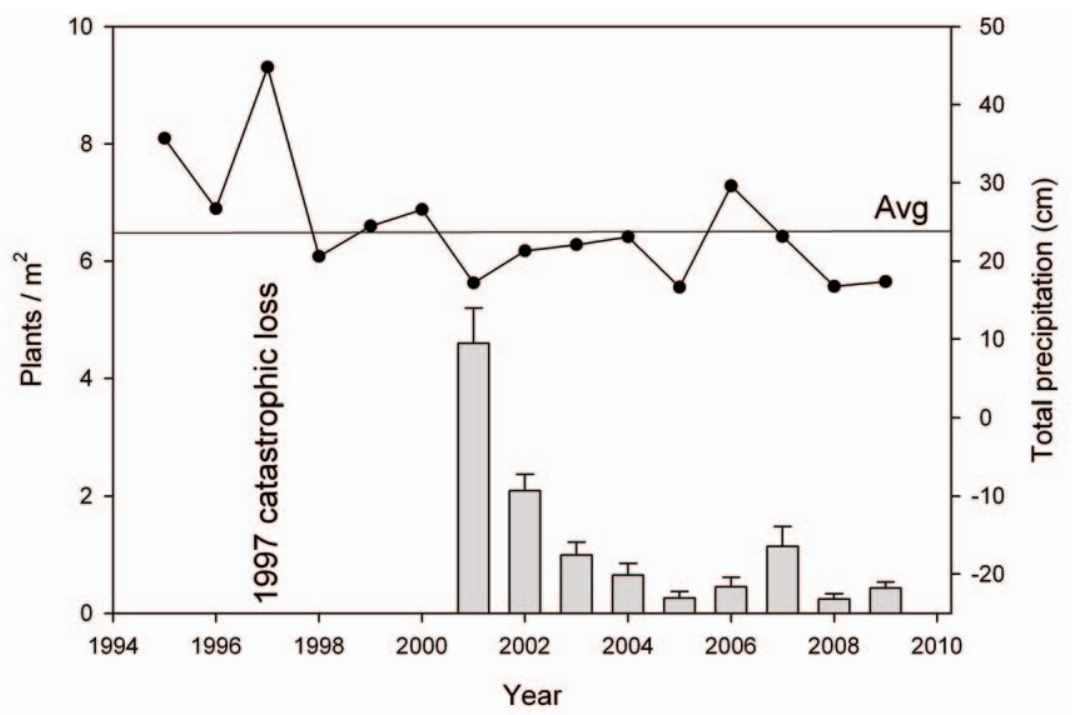

Fig. 5. Density of velvet lupine (Lupinus leucophyllus; bars) and water year precipitation (lines). Error bars represent standard errors.

precipitation) affecting growth and photosynthesis of lupine are likely to affect the growth or even survival of the developing buds. Pitelka (1977) reported that the perennial lupine, Lupinus variicolor, partitioned the greatest proportion of energy $(40 \%)$ to its large tap root system during active growth in May-July, where the energy was stored for future growth.

In our quadrat study, density of mature lupine was correlated with spring precipitation $(r=0.77)$, but it was also correlated with the previous year's total precipitation $(r=$ 0.61 ) and with the previous year's spring precipitation in the transect density study $(r=$ 0.62 ). These correlations support the physiological activities of vigorous growth and the development of next year's perennating buds. Correlations with fall precipitation in the transect density study $(r=0.75)$ could be related to the continued growth and development of these buds, even though top growth may not be active. Timely summer precipitation in the quadrat density study $(r=0.50)$ and current year's total precipitation in the transect density study $(r=0.85)$ would be important for the survival of new seedlings. However, there was no evidence of a large increase in seedling survival and recruitment to support another outbreak of velvet lupine during this study, albeit precipitation was below average for most of the study.

\section{Conclusions}

Populations of velvet lupine cycle and appear to be related to seasonal precipitation patterns in the Channeled Scabland region of eastern Washington. A series of years with high precipitation led to outbreaks of velvet lupine populations, and these populations died back in subsequent years of below-average precipitation. Summer precipitation appears critical for survival of new seedlings. Previous spring precipitation may be necessary for development of perennating buds, and current water year fall precipitation may be necessary for the continued development of the buds. There was some variation in lupine seedling survival and subsequent density of mature plants throughout the region, suggesting that microclimatic factors affect lupine populations. Specific storms, soil types, and water and temperature stress all influence local velvet lupine populations. But generally, velvet lupine populations appear to cycle with weather patterns, increasing following wet years and dying back in drought.

\section{Literature Cited}

Black, R.A., AND R.N. Mack. 1986. Mount St. Helens ash: recreating its effects on the steppe environment and ecophysiology. Ecology 67:1289-1302.

Bratine, J.H., AND L.C. Bliss. 1999. Comparative physiological ecology of lupines colonizing early successional 
habitats on Mount St. Helens. Ecology 80:891-907. Available from: http://www.jstor.org/stable/1938349

CABLE, D.R. 1975. Influence of precipitation on perennial grass production in the semidesert southwest. Ecology 56:981-986.

Del Moral, R., AND C. Jones. 2002. Vegetation development on pumice at Mount St. Helens, USA. Plant Ecology 162:9-22

Gay, C.C., K.E. Panter, E. Motteram, J.M. Gay, H. Hantz, T. Wierenga, and T. Platt. 2007. Risk factors for lupine-induced crooked calf disorder in east-central Washington State. Pages 156-164 in K.E. Panter, T.L. Wierenga, and J.A. Pfister, editors, Poisonous plants: global research and solutions. CABI Publishing, Cambridge, MA

KEELER, R.F. 1976. Lupin alkaloids from teratogenic and nonteratogenic lupins. III. Identification of anagyrine as the probable teratogen by feeding trials. Journal of Toxicology and Environmental Health 1:878-889.

Kreps, L.B. 1969. The alkaloids of Delphinium occidentale S. Wats. Doctoral dissertation, Utah State University, Logan, UT.

MorRIS, W.F., AND D.M. WoOD. 1989. The role of lupine in succession on Mount St. Helens: facilitation or inhibition? Ecology 70:697-703.

PFister, J.A., AND D. COOK. 2011. Influence of weather on low larkspur (Delphinium nuttallianum) density. Journal of Agricultural Science 3(1):36-44. Available from: http://www.ccsenet.org/journal/index.php/jas/ index

PitelKA, L.F. 1977. Energy allocation in annual and perennial lupines (Lupinus: Leguminosae). Ecology 58:1055-1065.

RalphS, M.H. 2009. Response of broom snakeweed (Gutierrezia sarothrae) and cool-season grasses to defoliation. Invasive Plant Science and Management $2: 28-35$.
RalphS, M.H., AND D.R. Gardner. 2001. Influence of defoliation on toxic alkaloid concentration and alkaloid pools in tall larkspur. Journal of Chemical Ecology 71:151-160.

Ralphs, M.H., and D.T. Jensen. 2007. Population cycles of poisonous plants. Pages 423-437 in K.E. Panter, T.L. Wierenga and J.A. Pfister, editors, Poisonous plants: global research and solutions. CABI Publishing, Cambridge, MA.

Ralphs, M.H., J.A. Pfister, S.L. Welsh, J.D. Graham, J. Purvines, D.T. Jensen, and L.F. James. 2003. Locoweed population cycles. Rangelands 25(5):14-18.

Rau, B.M., D.W. JOHNSON, R.R. BLANK, and J.C. CHamBERS. 2008. Prescribed fire, soil and plants: burn effects and interactions in the central Great Basin. Rangeland Ecology and Management 61:169-181.

Shupe, J.L. W. Binns, L.F. James, and R.F. Keeler. 1967. Lupine, a cause of crooked calf disease. Journal of the American Veterinary Medical Association 151:198-203.

SNEVA, F., AND C.M. BRITTON. 1983. Adjusting and forecasting herbage yields in the Intermountain Big Sagebrush Region of the Steppe Province. Oregon State University Agricultural Experiment Station Bulletin 659, Corvallis, OR.

Sosebee, R.E., D.B. Wester, J.C. Villalobos, C.M. Britton, C. Wan, and N. Hisham. 2003. Pages 60-71 in Proceedings of the 2nd National Conference on Grazing Lands. Grazing Lands Conservation Initiative, Society for Range Management, Wheatridge, CO.

Tracy, B.F., and S.J. MCNaughton. 1997. Elk grazing and vegetation response following late season fire in Yellowstone National Park. Plant Ecology 130:111-119.

Received 5 August 2010 Accepted 18 May 2011 